\title{
PERBANDINGAN LUTHER DAN CALVIN DALAM PENAFSIRAN TERHADAP KHOTBAH DI BUKIT
}

\author{
Joshua Timothy Siwalette \\ Sekolah Tinggi Reformed Injili Internasional \\ Korespondensi: Algathier@gmail.com
}

\begin{abstract}
ABSTRAK: Khotbah di bukit merupakan salah satu perikope paling terkenal dalam Alkitab, namun sayangnya memiliki polemik penafsiran dalam kalangan reformed. Artikel ini akan menganalisa dua penafsiran khotbah di bukit dari dua tokoh reformed terkenal yaitu John Calvin dan Martin Luther untuk menemukan titik terang dari permasalahan. Artikel ini akan menunjukan bahwa penafsiran Calvin lebih bertanggung jawab dari Luther, namun ada aspek keindahan aplikasi yang bisa pembaca pelajari dari Luther.

KATA KUNCI: Penafsiran, Khotbah dibukit, John Calvin, Martin Luther, Kritik Historika, Taurat dan Injil.

ABSTRACT: The Sermon on the Mount is one of the most famous passages in the Bible, but unfortunately it has a polemic interpretation in the reformed circles. This article analyzes two interpretations of the Sermon on the Mount from two well-known reformed figures, John Calvin and Martin Luther, to discover the heart of the problem. This article shows that Calvin's interpretation is more responsible than Luther's, but there is a beautiful legitimate application that readers can learn from Luther.
\end{abstract}

KEYWORDS: Interpretation, Sermon on the Mount, John Calvin, Martin Luther, historical criticism, law and gospel.

\section{Pendahuluan}

Di dalam sejarah kekristenan ada sebuah perikop Alkitab, yang memiliki pengaruh besar dalam kekristenan. Nama perikop itu adalah khotbah di 
bukit. ${ }^{1}$ Tidak hanya memiliki pengaruh besar terhadap kekristenan, menurut Warren Kissinger salah seorang ahli khotbah di bukit. Khotbah ini memiliki pengaruh yang besar juga kepada orang bukan Kristen. ${ }^{2}$

Namun sayangnya perikop penting ini menjadi sumber perdebatan karena banyaknya macam penafsiran akan makna khotbah ini. Grant Osborne saja mengatakan bahwa sepanjang sejarah ada sembilan macam penafsiran. ${ }^{3}$ Dalam kalangan Reformed sendiri pendekatan kepada teks ini terbagi menjadi dua jenis interpretasi. Pertama, inaugurated eschatology/view. Pandangan ini mengajarkan bahwa etika khotbah di bukit harus ditaati, bukan sebagai cara mendapatkan keselamatan seperti yang ditawarkan medieval approach ataupun Anabaptist, melainkan sebuah ketaatan yang lahir dari saya syukur akibat sudah diselamatkan oleh Tuhan Yesus (gratitude ethic). ${ }^{4}$

Sedangkan pandangan yang kedua adalah Luther's/Lutheran approach. Pandangan ini memandang ajaran etika dari khotbah di bukit sebagai impossible ethic. Dalam artian pandangan ini melihat bahwa etika yang diajarkan oleh khotbah ini mustahil dilakukan oleh orang percaya, oleh sebab itu maka tujuan dari ajaran etika ini bukanlah untuk ditaati. Melainkan untuk menyadarkan manusia betapa berdosanya diri mereka, sehingga mereka sadar bahwa butuh keselamatan dari Tuhan Yesus. ${ }^{5}$

Alasan artikel ini ditulis karena adanya polemik penafsiran dikalangan Reformed yang sudah terjadi sejak zaman Reformasi. John Calvin sebagai penafsir inaugurated view dikatakan sebagai seorang Legalis ataupun disebut sebagai orang yang bukan beragama Kristen melainkan Yahudi. ${ }^{6} \mathrm{Hal}$ seperti ini rupanya berlangsung hingga zaman sekarang. Di mana denominasi Lutheran masih melihat mereka yang menafsirkan secara inaugurated view adalah seorang Legalis. ${ }^{7}$ Dan bahkan Michael Horton yang bukanlah

\footnotetext{
1 David P. Scaer, "Sermon on the Mount," Evangelical Dictionary of Biblical Theology, Baker Reference Library (Grand Rapids: Baker Book House, 1996), 723.

2 Warren S. Kissinger, The Sermon On the Mount: a History of Interpretation and Bibliography (Metuchen, N.J.: Scarecrow Pr, 1975), xi.

3 Grant R. Osborne, Matthew, Zondervan Exegetical Commentary On the New Testament (Grand Rapids, MI: Zondervan, 2010), 159.

4 Diambil dari bagian bab 5.13 berjudul "Theological interpretation of sermon on the mount" yang diposting secara gratis oleh baker publisher, dari buku: Mark Allan Powell. Introducing the New Testament: a Historical, Literary, and Theological Survey. Grand Rapids, MI: Baker Academic, 2015. Di dalam alamat website: http:// bakerpublishinggroup.com/books/introducing-the-new-testament/264690/esources/chapters/93 (diakses: 21/02/2017).

5 Graham N. A.Stanton, Gospel for a New People: Studies in Matthew (Louisville, KY: Westminster/John Knox Press, 1993), 129.

6 Jesse Couenhouven, "Law and Gospel, or the Law of the Gospel? Karl Barth's Political Theology Compared with Luther and Calvin," Journal of Religious Ethic 30, no. 2 (2002), 153, diakses pada 18 Januari 2017, ngtt. journals.ac.za/pub/article/download/119/216.

7 Mtata, Kenneth, and Craig R. Koester, To All the Nations: Lutheran Hermeneutics and the Gospel of Matthew (Geneva, Switzerland: Lutheran World Federation, 2015), 29, diakses pada 18 Desember 2016,
} 
kaum Lutheran namun memilik cara tafsir yang sama, berani mengatakan bahwa mereka yang tidak menafsirkan dengan cara Law and Gospel (Cara hermeneutika Luther) membawa Kekristenan kepada Christless Christianity. ${ }^{8}$

Di tengah kondisi seperti ini maka penulis melihat perlunya meninjau apakah memang betul pandangan inaugurated view/gratitude ethic tidak bertanggung jawab dan merupakan kebangkitan Legalisme, atau sebaliknya impossible ethic Lutheran yang salah.

Untuk menemukan ini maka penulis memilih dua tokoh untuk dianalisa pandangannya terhadap ajaran etika dari khotbah di bukit, yaitu Martin Luther dan John Calvin. Ada dua alasan kenapa penulis memilih kedua tokoh ini karena kedua tokoh inilah tokoh terkenal yang mulai menawarkan kembali penafsiran berbeda melihat khotbah di bukit setelah mayoritas pandangan dikuasai oleh medieval approach. Pertama, Luther adalah orang yang memulai penafsiran impossible ethic dari khotbah di bukit. ${ }^{9}$ Kedua, penulis memilih Calvin dengan alasan keunikan penafsiran Calvin. Memang penafsiran yang mengarahkan kepada mentaati ajaran khotbah di bukit oleh semua orang Kristen yang Calvin lakukan bukanlah sesuatu yang baru. Karena sebelum medieval approach menjadi dominan, penafsiran tokoh besar Kristen seperti Chrysostom, Tertullian, dan Agustinus menafsirkan ajaran khotbah di bukit sebagai ajaran yang harus di taati oleh semua orang Kristen tanpa kecuali. Pandangan ini mulai berubah semenjak zaman kaisar Constantine, dan semakin dominan melalaui Penafsiran dari Thomas Aquinas yang mengajarkan pandangan medieval approach. ${ }^{10}$ Namun Calvin memiliki penekanan ketaatan yang kuat sebagai bentuk gratitude dalam khotbah ini di bandingkan dengan yang lain yang dimana penekanan gratitude akan menjadi penekanan dari inaugurated view di zaman sekarang. Hal ini menurut Stephen R. Spencer dapat dilihat dari betapa seringnya dia mengingatkan ucapan syukur kepada pembacanya di dalam khotbah di bukit. Berikut kalimat dari Spencer.

"He reiterates it in his exposition at every opportunity. To follow Jesus is to submit to his teaching, to respond from the heart with faithful obedience born of love and

https://www.lutheranworld.org/sites/default/files/dtpw-studies-201502-to_all_nations-full.pdf.

8 Michael Scott Horton. Christless Christianity: The Alternative Gospel of the American Church: Baker Pub Group, 2012), 109.

9 Untuk sejarah penafsiran khotbah di bukit zaman reformasi lihat R. A. Guelich, "Interpreting the Sermon on the Mount," Interpretation: A Journal of Bible and Theology 41, no. 2 (January 1987): 117-130, diakses pada 10 Januari 2017, http://journals.sagepub.com/doi/abs/ 10.1177/002096438704100202. Untuk penafsiran medieval lihat, Ulrich Luz, Matthew 1-7: A Commentary on Matthew 1-7, ed. Helmut Koester, Rev. ed., Hermeneia-a Critical and Historical Commentary on the Bible (Minneapolis, MN: Fortress Press, 2007), 178.

10 Kissinger melakukan penelitian kepada naskah-naskah sebelum zaman reformasi yang menginterpretasi khotbah di bukit dan mengambil kesimpulan seperti yang di tulis di atas. Untuk penafsiran lebih detail dari Chrysostom, Tertullian, dan Agustinus, dapat dilihat di bukunya. Warren S. Kissinger, The Sermon On the Mount, 5-16. 
gratitude in response to gracious redemption."11

Karena semua alasan ini maka artikel ini dituliskan, untuk melihat titik terang dari perdebatan ini sekaligus menarik pelajaran yang bisa ditarik dari polemik penafsiran yang ada. Artikel ini akan dimulai dengan penafsiran Luther, lalu penafsiran John Calvin, dan diakhiri dengan evaluasi terhadap dua penafsiran.

\section{Penafsiran Martin Luther: Law and Gospel}

Penafsiran dengan cara Luther merupakan gaya penafsiran yang baru pada zamannya. Karena sebelumnya dari zaman Aquinas hingga zaman Luther kebanyakan orang Kristen menafsirkan dengan cara hierarki (dikenal sebagai medieval approach). ${ }^{12}$ Pandangan ini mengatakan bahwa ajaran etika yang terdapat dalam khotbah di bukit merupakan ajaran yang baik untuk semua orang Kristen, namun ajaran di dalam khotbah di bukit hanya bernuansa wajib bagi mereka yang memiliki jabatan di dalam gereja seperti, bishop, pastor, suster, paus, dan lain-lain.

Dan akibat penafsiran dengan cara seperti ini membuat khotbah di bukit menjadi kurang bersuara di kalangan awam dalam zaman medieval. Inilah yang menyebabkan mengapa Luther mengkhotbahkan penafsirannya akan khotbah di bukit, salah satu tujuannya adalah untuk menyerang nuansa hierarki ini dan mengembalikan supaya suara dari khotbah ini juga berlaku bagi mereka kalangan awam di dalam gereja. Meskipun ketika suara ini ketika dikembalikan kepada kalangan awam akan memiliki penekanan yang berbeda.

Dalam pengajarannya melalui kitab Roma, di sana Luther menunjukkan hermeneutikanya, yang nantinya akan diadopsi oleh para Lutheran.

"The real difference between the old and the new law [read: gospel] is this: The old law says to those who are proud in their own righteousness: You must have Christ and his spirit; the new law says to those who humbly recognize that they lack all righteousness and who seek Christ: Behold, here is Christ and his spirit! They therefore, that interpret the gospel as something else than "good news," do not understand the gospel. Precisely this must be said of those who have turned the gospel into a law rather than interpret it as grace, and who set Christ before us as a Moses." 13

11 Jeffrey P. Greenman, Timothy Larsen, and Stephen R. Spencer, The Sermon On the Mount through the Centuries (Grand Rapids, Mich: Brazos Press, 2007), 148.

12 Mark Allan Powell, Introducing the New Testament: a Historical, Literary, and Theological Survey (Grand Rapids, MI: Baker Academic, 2009), 120.

13 Martin Luther, Lectures on Romans, Wilhelm Pauck, ed. and trans. LCC, XV (Philadelphia: Fortress Press, 1961), 199. 
Hermeneutika law and gospel Luther terlihat lebih jelas lagi di dalam kritiknya terhadap Erasmus. Dimana menurutnya Erasmus tidak membaca Alkitab dengan cara law and gospel.

"In these passages, our friend Diatribe makes no distinction whatever, between the voice of the Law and the voice of the Gospel: because, forsooth, it is so blind and so ignorant, that it knows not what is the Law and what is the Gospel. For out of all the passages from Isaiah, it produces no one word of the law, save this, 'If thou wilt;' all the rest is Gospel, by which, as the word of offered grace, the bruised and afflicted are called unto consolation. Whereas, the Diatribe makes them the words of the law. But, I pray thee, tell me, what can that man do in theological matters, and the Sacred Writings, who has not even gone so far as to know what is Law and what is Gospel"14

Maka tidak heran gereja Lutheran memakai law and gospel sebagai alat penafsiran.

Dengan cara penafsiran seperti ini maka bagi Luther isi Alkitab dapat dibagi menjadi dua bagian yaitu antara hukum dan injil. Berikut adalah komentar Jaroslav Pelikan mengenai penafsiran Luther.

"Therefore it was used in the singular, and the distinction between the law and gospel, which was for Luther the fundamental distinction of all theology, was a difference not between two books, but between two messages, both of which were contained in the Old Testament as well as in the New Testament."15

Maksud Luther dalam hal ini adalah, isi Alkitab hanya berbicara mengenai dua hal. Entah itu adalah injil yang menunjukkan pengharapan dan keselamatan, atau hukum yang akan menuntut, menghukum, membuat putus asa sehingga pembaca mau tidak mau menyadari membutuhkan Kristus. Dengan kata lain hermeneutika Luther ujung-ujungnya akan mengarah kepada Injil Keselamatan Tuhan Yesus. Dikarenakan pembacaan hukumpun tujuannya akan mengarah kepada injil.

Akibat dari pembacaan Luther seperti ini langsung terlihat di dalam zaman Luther sendiri. Misalnya saja Luther tidak memasukkan kitab Yakobus yang menekankan perbuatan baik ke dalam kanon Alkitab dan hanya ditaruh di dalam apendiks, dan dia menyebutnya sebagai kitab jerami. ${ }^{16} \mathrm{Hal}$ ini terjadi karena ketika Luther memakai penafsiran law and gospel dia sama sekali tidak menemukan penginjilan di dalamnya dan yang ada hanya tuntutan untuk berbuat baik. Berikut adalah kalimat Luther dalam pendahuluannya untuk kitab Yakobus.

14 Martin Luther, The Bondage of the Will (Eerdmans publishing co.Sovereign grace union, 1931), 66.

15 Jaroslav Pelikan, Divine Rhetoric: the Sermon On the Mount as Message and as Model in Augustine, Chrysostom, and Luther (Crestwood, NY: St Vladimir's Seminary Press, 2000), 90.

16 Henry Krabbendam, The Epistle of James: Tender Love in Tough Pursuit of Total Holiness: a Commentary (Bonn: Verlag für Kultur und Wissenschaft, 2006), 122. 
"Whatever does not teach Christ is not apostolic, even though. St. Peter or St. Paul does the teaching. Again, whatever preaches Christ would be apostolic, even if Judas, Annas, Pilate, and Herod were doing it."17

Tidak heran karena penekanan Luther akan hermeneutika ini, maka pengikut setelahnya juga memiliki metode penafsiran yang sama. Hal ini terlihat dalam kamus besar Lutheran dalam bagian khotbah dikatakan bahwa "The purpose of Christian preaching is to proclaim to a sinful world the Grace of God in Christ Jesus". ${ }^{18}$ Dan di dalam kamus ini juga dikatakan bahwa isi Alkitab hanya dua Law and Gospel. ${ }^{19}$ Dengan kata lain membuat khotbah ataupun penafsiran harus dengan cara Law and Gospel yang Luther ajarkan.

Nantinya dalam Penafsiran Luther terhadap khotbah di bukit akan ditemukan dua nuansa. Pertama di bagian awal komentari atau bagian pasal lima dari komentari, Luther menafsirkan khotbah ini secara third law yang dimana ini berlawanan dengan semangat hermeneutika law and gospel. Karena dalam bagian awal ini Luther mengajak orang Kristen untuk menghidupi ajaran etika yang diajarkan di dalam khotbah di bukit. Berikut adalah perkataan Luther.

"Therefore they speak and exhort much about good works; as indeed both should in Christendom be insisted upon, yet each in proportion to its nature and dignity: that one should first and most of all hold forth faith and Christ, and afterwards inculcate works." 20

Namun di dalam bagian lain dari komentari Luther akan khotbah ini, juga ditemukan kalau dia menafsirkan secara law and gospel. Ini berarti Luther melihat ajaran di dalam khotbah di bukit sebagai Taurat yang dituliskan dengan tujuan utama bukan untuk ditaati melainkan untuk menunjukkan keberdosaan pembacanya dan menyadarkan mereka bahwa mereka sesungguhnya membutuhkan Tuhan Yesus sebagai juruselamat. Berikut adalah kalimat Luther dari penafsirannya akan Matius 5:16 yang tertulis di komentarinya.

"How we are not able to fulfill properly a tittle of it of ourselves. And although after we have become Christians by baptism and faith, we do as much as we can, we still can never thereby stand before God; but must always humbly find our way to Christ, who has most purely and perfectly fulfilled it all, and bestows himself with his fulfillment of it upon us, so that through him we may stand before God, and the law cannot hold

17 Martin Luther, dan John Dillenberger, Martin Luther, Selections from His Writings (Garden City, NY: Doubleday, 1961), 35.

18 Erwin Louis Lueker, Lutheran Cyclopedia (St. Louis: Concordia Publ. House, 1975), 836.

19 Ibid, 836.

20 Martin Luther, Commentary on the Sermon on the Mount (Philadelphia: Lutheran Publication Society, 1892), 68 . 
us guilty or condemn us."21

Maka dapat dilihat bahwa di dalam komentari Luther sendiri terdapat keambiguan dalam cara penafsirannya. Di dalam komentari di bagian pasal awal khotbah di bukit dia menafsirkan secara third law. Namun dalam bagian akhir dari komentari dia justru menafsirkan secara law and gospel. Dan ini yang membuat Luther ambigu dalam hal ini. Hal ini disadari oleh teolog Perjanjian Baru bernama Graham Stanton yang mengatakan.

"Luther also discussed the sermon in terms of law and gospel. In some of his writings he emphasized that the sermon is the law of Christ that makes people aware the gospel of God's grace through Christ... But in other passages Luther stated that the sermon is not just the accusing law... By reffering in different passages in his writings to the Sermon both as law and gospel, Luther confused some of his later followers."22

Meskipun ambigu namun cara penafsiran Luther terlihat sangat jelas masih law and gospel ketika melihat khotbah Luther dari khotbah di bukit. Dalam khotbah Luther pada Matius 5:16-20, Luther dengan sangat jelas menunjukan cara penafsirannya kepada khotbah ini.

"For this reason Christ's action on this occasion is to be considered one of great benefit to us, in that he teaches us where we fail and come short. Here he particularly treats of the failings due to wrath, which causes so much havoc among men, as is seen on every side, yea, nearly the whole world is under its sway." ${ }^{23}$

Pada teks di atas terlihat bahwa Luther melihat khotbah di bukit diberikan kepada pendengar untuk menyadarkan mereka bahwa mereka berdosa. Tidak heran karena Luther sendiri mengkategorikan injil Matius, sebagai injil isinya lebih dominan kategori law, maka dari itu kitab Injil ini tidak menjadi favorit Luther. Berikut adalah kalimat Luther.

"as indeed both should in Christendom be insisted upon, yet each in proportion to its nature and dignity: that one should first and most of all hold forth faith and Christ, and afterwards inculcate works. Since now the evangelist John has most thoroughly and powerfully discussed the main topic, and is rightly therefore regarded as the highest and foremost evangelist" 24

Dalam bagian lain dari khotbah ini Luther menunjukkan bahwa tujuan dari teks ini adalah untuk menyadarkan manusia terhadap dosanya dimana ini adalah tujuan dari hermeneutika law and gospel.

21 Ibid, 76.

22 Stanton, A Gospel for a New People, 292.

$23 \mathrm{http}: / /$ www.trinitylutheranms.org/MartinLuther/MLSermons/Matthew5_20_26.html (diakses: 19/02/2017)

24 Luther, Commentary, 63. 
"What then must we do? You must do as follows: You must acknowledge that you are condemned by the law, and the devil's own property and that you are unable to rescue yourself by any power of your own. Therefore you must flee to God, pray him to change you, or all is lost and ruined." 25

Dikarenakan cara penafsiran yang sudah dijelaskan di atas, maka Luther tidak akan menafsirkan ini sebagai ajaran etika yang harus dikejar. Melainkan etika yang mustahil untuk diikuti, dengan tujuan manusia sadar akan keberdosaanya dan membutuhkan Tuhan Yesus.

Luther di dalam penafsiran kepada Khotbah di bukit mengatakan bahwa Khotbah di bukit adalah bagian dari Alkitab yang termasuk "law" di dalam cara baca law and gospel. Hal ini dikarenakan isi dari khotbah dibukit yang banyak berbicara perintah untuk hidup taat. Kenyataan ini Luther utarakan di dalam komentarinya.

"That is to say, however: 'That they may see your good works and glorify your Father which is in heaven,' is spoken after the manner of St. Matthew, who is in the habit of speaking in this way of works. For he, together with the other two evangelists, Mark and Luke, does not in his gospel treat so fully and profoundly upon the great subject of Christ as St. John and St. Paul. Therefore they speak and exhort much about good works"26

Karena itu tidak heran kalau Teolog Bern Oberndorfer mengatakan bahwa perikop khotbah ini merupakan perikop yang sangat menantang untuk ditafsirkan oleh seorang Lutheran dikarenakan nuansa perbuatan baik yang begitu kental di dalamnya membuat sulit untuk mengimplementasikan cara penafsiran law and gospel yang Luther ajarkan. "In light of these factors, the Sermon on the Mount in Matthew 5-7 is a particular challenge for interpreters, especially Lutheran interpreters. "27

Oleh sebab ini adalah bagian "law" dalam Alkitab menurut Luther maka perikop ini bukan bertujuan untuk mengajarkan etika Kerajaan Allah melainkan untuk menunjukkan kemustahilan mereka mengikuti semua ajaran ini semua sehingga mereka yang membaca merasakan putus asa dengan tujuan pembaca dapat menyadari bahwa diri mereka berdosa dan membutuhkan Kristus. Dan kesadaran ini yang dirindukan oleh Tuhan Yesus dalam perikop ini menurut Luther, karena dengan demikian mereka akan mencari keselamatan dari Tuhan Yesus.

Maka dari itu ada dua pengajaran dari Luther yang bisa ditarik dari khotbah di bukit. Pertama, cara menafsirkan khotbah di bukit adalah bagian

\footnotetext{
$25 \mathrm{http} / /$ www.trinitylutheranms.org/MartinLuther/MLSermons/Matthew5_20_26.html (diakses: 19/02/2017).

26 Luther, Commentary, 63.

27 Mtata, To All the Nations, 76.
} 
law dalam Alkitab menurut kacamata law and gospel. Kedua, karena khotbah ini ada di kategori law maka khotbah ini bertujuan untuk menuntut dan menghukum pembacanya dengan tujuan mereka sadar diri mereka berdosa dan membutuhkan Tuhan Yesus. Bagi Luther khotbah dibukit adalah Christocentric, dalam artian mengarahkan pembaca kepada kesadaran akan dosa sehingga mau percaya kepada Tuhan Yesus sebagai juruselamat.

\section{Penafsiran John Calvin: Historical Criticism}

Teknik hermeneutika Calvin tidaklah terlepas dari pada zaman di mana dia dilahirkan. Calvin lahir di tengah zaman yang sangat dipengaruhi oleh semangat Humanisme yang sedang berkembang pesat pada zaman itu. "By sixteenth century... With the rise of humanism in the Renaissance, the need for careful literary and historical interpretation of ancient literature was widely recognized." ${ }^{28}$ Semangat humanisme ini memunculkan cara baca yang dikenal sebagai Historical Criticism. Cara baca ini di jelaskan oleh William Yarchin sebagai berikut.

"The humanist quest for the best manuscript readings and attentiveness to the grammar and style of the original language expressions were fueled by the desire to discern the genuine meaning of the ancient text, that is the meaning that was in the mind of the author." 29

Melihat kalimat di atas maka dapat ditarik kesimpulan bahwa tujuan utama dari cara baca ini adalah, berusaha untuk menemukan author's intended meaning dari setiap kitab dalam Alkitab. Mengenai teknik ini Gordon Fee mengatakan,

"Exegesis, therefore, answers the question, What did the biblical author mean?... exegesis is primarily concerned with intentionality: What did the author intend his original readers to understand?"30

Dan cara baca historical criticism ini akhirnya menyentuh dan mempengaruhi Calvin dalam masa studinya.

"During this time he made his acquaintance with the new learning of the Renaissance, Pierre del'Etoile and the great Andrea Alciati introduced him to the historical-critical method of studying law" ${ }^{\prime \prime 1}$

28 David L. Puckett, John Calvin's Exegesis of the Old Testament (Louisville, KY: Westminster John Knox Press, 1995), 4.

29 William Yarchin, History of Biblical Interpretation: a Reader (Grand Rapids, MI: Baker Academic, 2011), 184.

30 Gordon D. Fee, New Testament Exegesis: a Handbook for Students and Pastors (Louisville, Kentucky.: Westminster John Knox Press, 2002), 27.

31 Donald K. McKim, Encyclopedia of the Reformed Faith (Louisville, KY: Westminster John Knox Press, 1992), 45 . 
Dalam melakukan hermeneutika historical critiscism, berarti Calvin memiliki tujuan untuk menemukan original meaning dari teks Alkitab yang ditafsirkan. Berikut adalah kalimat Calvin dalam introduksi komentari kitab Roma.

"since it is almost his only work to lay open the mind of the writer whom he undertakes to explain, the degree in which he leads away his readers from it, in that degree he goes astray from his purpose, and in a manner wanders from his own boundaries." 32

Bahkan begitu pentingnya untuk menemukan author's intended meaning ini sampai-sampai Calvin menegur penafsir yang menurut Calvin gagal menemukan author's intended meaning, berikut adalah kalimatnya dalam komentari kitab Amos "But it seems to me that the Prophet's design is another, which interpreters have not sufficiently weighed". 33 Berikut juga adalah kalimat Calvin yang menunjukkan pentingnya mendapatkan author's intended meaning di dalam kitab Yesaya.

"But this interpretation does not appear to me to agree well with the text. Sometimes it happens that, when a sentence is beautiful, it attracts us to it, and causes us to steal away from the true meaning, so that we do not adhere closely to the context, or spend much time in investigating the author's meaning. Let us therefore inquire if this be the true meaning of the Prophet." 34

Untuk mencapai tujuannya ini menurut David Puckett, Calvin berusaha mencari dua aspek penting dari teks yang akan ditafsir. Pertama adalah historical context, dan yang kedua adalah literary context. ${ }^{35}$

Apa yang dimaksud dengan historical context adalah usaha untuk menemukan konteks kehidupan sosial, politik, budaya, pada zaman teks itu ditulis. Dengan tujuan dapat mengetahui keadaan saat penulis menulis teks tersebut dan siapa pembaca mula-mulanya, sehingga dapat membaca makna dari pesan Alkitab dengan tepat. Berikut adalah kalimat dari Gordon Fee.

"The historical context, which will differ from book to book, has to do with several matters: the time and culture of the author and audience, that is, the geographical, topographical, and political factors that are relevant to the author's setting; and the historical occasion of the book, letter, psalm, prophetic oracle, or other genre. All such matters are especially important for understanding." ${ }^{\prime 36}$

32 John Calvin, Commentary on Romans (Grand Rapids, MI: Christian Classics Ethereal Library), 12, diakses pada 10 Februari 2017, https://www.ccel.org/ccel/calvin/calcom38.html.

33 John Calvin, Commentary on Joel, Amos, Obadiah (Grand Rapids, MI: Christian Classics Ethereal Library), 12, diakses pada 10 Februari 2017, https://www.ccel.org/ccel/calvin/calcom27.html

34 John Calvin, Commentary on Isaiah - Volume 2 (Grand Rapids, MI: Christian Classics Ethereal Library), 255, diakses pada 10 Februari 2017, https://www.ccel.org/ccel/calvin/calcom14.html.

35 Puckett, John Calvin's Exegesis, 64.

36 Fee, How to Read, 30. 
Bagi Calvin mengetahui historical context dari suatu teks dalam Alkitab merupakan hal penting untuk menemukan makna yang ingin disampaikan penulis, berikut kalimat Calvin dari argumentum dalam kitab Ratapan "I undertake now to explain The Lamentations of Jeremiah. We must inquire when the Book was composed by the Prophet, and also what was the object of the author". ${ }^{37}$ Dan dalam komentarinya dari Zakaria 2:6, dia mengatakan "That the design of the Prophet may be more clear, we must especially bear in mind the history of the case" ${ }^{38}$ Dari berapa kutipan diatas tidak heran kalau Thomas Parker menarik kesimpulan bahwa "one of the outstanding features of Calvin's exposition of Prophets is his historical treatment". ${ }^{39}$

Sedangkan apa yang dimaksud dengan literary context adalah usaha Calvin untuk membaca sebuah teks alkitab dengan tidak terlepas dari alur penulis ataupun jenis tulisan. Berikut adalah kalimat yang menunjukan pentingnya literary context bagi Calvin dalam menafsirkan Injil Yohanes.

"To be lifted up means to be placed in a lofty and elevated situation, so as to be exhibited to the view of all. This was done by the preaching of the Gospel; for the explanation of it which some give, as referring to the cross, neither agrees with the context nor is applicable to the present subject" 40

Dalam penafsirannya terhadap Yohanes 3:14, Calvin menolak penafsiran beberapa orang (namanya tidak disebut oleh Calvin) yang menafsirkan bahwa tongkat ular dalam ayat empat belas menunjukkan kepada salib. Dasar penolakan ini bagi Calvin dikarenakan penafsiran tersebut tidak sesuai dengan konteks alur penulisan dari pada Injil Yohanes. Penekanan Calvin akan literary context ini diutarakan sebagai berikut oleh Randall C. Zachman.

"what is not as widely claimed is that Calvin was convinced that the mind, council, meaning, or sense of the author could only be revealed by the interpreter who carefully followed the order of the context of the Scripture being interpreted"11

Dari dua bagian ini maka jelas kalau dalam hermeneutika Calvin adalah penting untuk menemukan author's intended meaning. Dan cara Calvin

37 John Calvin, Commentary on Jeremiah and Lamentations - Volume 5 (Grand Rapids, MI: Christian Classics Ethereal Library), 202, diakses pada 10 Februari 2017, https://www.ccel.org/ccel/calvin/calcom21. html.

38 John Calvin, Zechariah, Malachi (Grand Rapids, MI: Christian Classics Ethereal Library), 61, diakses pada 10 Februari 2017, https://www.ccel.org/ccel/calvin/calcom30.html.

39 Thomas Henry Louis Parker, Calvin's Old Testament Commentaries (Edinburgh: T \& T Clark, 1993), $205-56$.

40 John Calvin, Commentary on John - Volume 1 (Grand Rapids, MI: Christian Classics Ethereal Library), 69, diakses pada 10 Februari 2017, https://www.ccel.org/ccel/calvin/calcom34.html.

41 Randall C. Zachman, "Gathering Meaning from the Context: Calvin's Exegetical Method" dalam The Journal of Religion 82, no. 1 (2002), 6, diakses pada 16 Januari 2017, https://www.jstor.org/stable/1205881. 
menemukan meaning ini adalah dengan memperhatikan historical context dan juga literaly context.

\section{Penafsiran Calvin Khotbah di Bukit}

Karena Calvin memakai historical criticism dalam melakukan eksegesis dari khotbah di bukit. Maka tidak heran kalau dia akan berusaha mencari author's intended meaning dari khotbah ini. Hal ini terlihat ketika dia menolak ajaran Katolik yang menurutnya alegoris dan lari dari tujuan teks khotbah di bukit.

"But it is highly ridiculous in the Papists, to construct their purgatory out of a continued allegory on this passage. Nothing is more evident than that the subject of Christ's discourse is the cultivation of friendship among men" ${ }^{\prime \prime 2}$

Karena Calvin memakai historical criticism dalam melakukan eksegesis dari khotbah di bukit. Maka tidak heran kalau dia akan berusaha mencari author's intended meaning dari khotbah ini. Hal ini terlihat ketika dia menolak ajaran Katolik yang menurutnya alegoris dan lari dari tujuan teks khotbah di bukit.

"But it is highly ridiculous in the Papists, to construct their purgatory out of a continued allegory on this passage. Nothing is more evident than that the subject of Christ's discourse is the cultivation of friendship among men"43

Penggunaan literary context dalam usaha Calvin menafsirkan khotbah di bukit dapat terlihat dari penafsirannya terhadap Matius 5:33.

"The Anabaptists, too, have blustered a great deal, on the ground, that Christ appears to give no liberty to swear on any occasion, because he commands, Swear not at all But we need not go beyond the immediate context to obtain the exposition: for he immediately adds, neither by heaven, nor by the earth Who does not see that those kinds of swearing were added by way of exposition, to explain the former clause more fully by specifying a number of cases?"44

Dalam kutipan ini Calvin berusaha menunjukkan bahwa interpretasi Anabaptis terhadap ajaran Tuhan Yesus mengenai sumpah adalah salah. Kesalahan ini Calvin tunjukan dengan memperlihatkan bahwa ajaran Tuhan Yesus mengenai larangan bersumpah harus dibaca dalam terang kalimat Tuhan Yesus selanjutnya yang akan memberikan makna kepada perintah dalam ayat sebelumnya.

Literary context yang paling jelas menurut penulis terlihat pada bagian pendahuluan dari khotbah di bukit, yaitu interpretasi Calvin terhadap Mat

42 John Calvin, Commentary on Matthew, Mark, Luke - Volume 1 (Grand Rapids, MI: Christian Classics Ethereal Library), 254, diakses pada 10 Februari 2017, https://www.ccel.org/ccel/calvin/calcom31.html.

43 Ibid.

44 Ibid, 259. 
5:1-2, dimana Calvin mengatakan "For the design of both Evangelists was, to collect into one place the leading points of the doctrine of Christ, which related to a devout and holy life.". ${ }^{45}$ Ayat ini menunjukkan dua hal mengenai pendekatan literary context Calvin terhadap khotbah di bukit. Pertama, Calvin melihat khotbah di bukit sebagai sebuah pengajaran dari Tuhan Yesus yang utuh, ada alur dan tidak dipisahkan, dan karena itu Calvin menyadari ada satu tujuan utama yaitu untuk mengajarkan etika kehidupan kudus bagi pengikut Kristus. Kedua, secara tidak langsung kita bisa melihat Calvin melakukan kritik redaksi. Bagi Calvin khotbah di bukit adalah kumpulan pengajaran Tuhan Yesus yang dikumpulkan oleh Matius, jadi khotbah ini bukanlah sesuatu yang terjadi dalam satu kejadian, melainkan banyak pengajaran Tuhan Yesus dari waktu terpisah yang dikumpukan. Kesimpulan ini Calvin ambil dikarenakan Calvin berusaha menganalisa literary context dari pada khotbah di bukit, dan dia merasa lebih meyakinkan untuk melihat teks ini sebagai ajaran-ajaran Tuhan Yesus yang terpisah yang dikumpulkan menjadi satu.

Sekarang dengan pendekatan history criticism yang berusaha melihat khotbah di bukit dari terang historical context dan literary context. Kesimpulan penafsiran Calvin dapat terlihat dari kutipan yang sudah penulis kutip sebelumnya. ${ }^{46}$ Di sini sangat jelas bahwa Calvin melihat bahwa ajaran etika dari khotbah di bukit harus ditaati oleh setiap orang Kristen. Penafsiran ini jelas sangat berbeda dengan Luther yang lebih menekankan kemustahilan dari etika tersebut.

Namun ketika Calvin mengajarkan ketaatan di dalam khotbah di bukit, sama sekali tidak ada maksud Calvin melihat ketaatan itu sebagai usaha manusia, atau salvation by works. Hal ini terlihat dari bagaimana Calvin memandang ketaatan dalam khotbah di bukit. Dalam interpretasi Calvin pada Matius 5:45, Calvin mengatakan mengenai ketaatan terhadap ajaran Tuhan Yesus di khotbah di bukit sebagai berikut "In short, Christ assures us, that this will be a mark of our adoption". ${ }^{47} \mathrm{Di}$ sini dapat dilihat bahwa Calvin tidak melihat Matius mengajarkan selamat karena etika yang baik, melainkan justru Calvin melihat bahwa apabila orang Kristen mentaati ajaran etika dari khotbah di bukit maka itu adalah tanda bahwa mereka sudah diselamatkan. Lebih jelas lagi dapat dilihat dari interpretasi Calvin pada ayat yang sama dimana Calvin mengatakan.

"Scripture frequently employs this manner of speaking, and represents as a reward the free gifts of God. The reason is, he looks at the design of our calling, which is, that,

45 Ibid, 230.

46 Ibid, 230.

47 Ibid, 269. 
in consequence of the likeness of God having been formed anew in us, we may live a devout and holy life. He maketh his sun to rise on the evil and the good, and sendeth rain on the just and the unjust." 48

Di dalam kutipan di atas dapat dilihat secara jelas bahwa Calvin melihat kalau setiap kali Alkitab menghendaki ketaatan seperti yang terjadi dalam khotbah di bukit, itu dikarenakan Tuhan menyadari kalau mereka yang sudah diselamatkan dan lahir baru sudah sewajarnya hidup kudus. Maka dari itu dapat disimpulkan bahwa ajaran etika yang ditarik oleh Calvin dari khotbah di bukit adalah gratitude ethic. Dikatakan gratitude karena etika yang Calvin ajarkan dari khotbah ini bukanlah keselamatan dari perbuatan baik, melainkan sebuah ketaatan yang muncul dalam kehidupan seorang Kristen sebagai ucapan terima kasih atau efek dari keselamatan yang Tuhan berikan, dan ini sesuai dengan kesimpulan yang James A. Hwyte mengenai etika dari Calvin,

"For John Calvin, 'the surest foundations of a well-regulated life' are in God's grace and our grateful response. 'Ever since God exhibited himself to us as a Father, we must be convicted of extreme ingratitude if we do not in our turn exhibit ourselves as his sons'. The Calvinist ethic is an ethic of grateful obedience." 49

John Hesselink juga mengambil kesimpulan yang sama. Menurutnya ketika Calvin menafsirkan sebuah ajaran Alkitab yang harus ditaati, maka itu adalah bentuk ucapan syukur umat Tuhan. Berikut kalimatnya.

"Calvin stressed also "the obedience of faith," a good Pauline term. He rejoices in the law of God, which now for Christians no longer threatens and curses but which in faith is the means by which they express their gratitude." ${ }^{50}$

Di dalam zaman sekarang apa yang Calvin ajarkan mengenai etika khotbah di bukit dikenal sebagai inaugurated view. Dikatakan inaugurated karena pandangan ini ingin mengajarkan bahwa khotbah di bukit adalah ajaran etika yang harus ditaati oleh orang Kristen dikarenakan kedatangan Kerajaan Allah sudah diinagurasi oleh Tuhan Yesus, dan mereka yang terkena dampak dari inagurasi ini dan sudah dikuasai hidupnya oleh Allah akan diubahkan semakin menghidupi apa yang khotbah di bukit ajarkan. Dengan kata lain, penafsiran pandangan inaugurated view ini secara garis besar sama seperti penafsiran Calvin. Mengapa penulis katakan secara garis besar, karena tentu saja secara spesifik ada penafsiran yang berbeda

48 Ibid, 269.

49 John Macquarrie and James F. Childress, The Westminster Dictionary of Christian Ethic (Philadelphia: Westminster, 1986), 71.

50 Donald K. McKim, The Cambridge Companion to John Calvin (Cambridge: Cambridge University Press, 2010), 82. 
antara semua penulis ini dengan Calvin, akan tetapi ketika memandang cara pengaplikasian ajaran etika dalam khotbah di bukit, mereka tetap satu suara yaitu harus ditaati karena sudah diselamatkan.

\section{Evaluasi}

Pengaplikasian dari pada ajaran etika khotbah di bukit dari Calvin sangatlah moderat, Calvin tidak jatuh kepada mengaplikasikannya secara radikal seperti Anabaptist, karena secara literary dan historical context dia tidak bisa menemukan justifikasi untuk menarik ajaran itu. Di lain pihak Calvin tidak menolak penekanan Matius akan kekudusan, sehingga dia juga tidak seperti Luther yang melihat etika tersebut mustahil dilakukan. Calvin sadar bahwa apa yang Matius ajarkan bukanlah esktrem kiri maupun kanan, maka dari itu yang Calvin tekankan adalah ethic of gratitude, yang penulis yakin merupakan keinginan Matius dan juga merupakan penengah dari dua kubu Luther dan Anabaptis.

Maka dari itu apabila ada yang mau menafsirkan khotbah di bukit sebagai ajaran ketaatan seperti Calvin maka itu bukanlah legalisme. Dikarenakan bagi Calvin khotbah di bukit bukan berbicara mengenai orang yang belum diselamatkan mengejar keselamatan, melainkan orang yang yang sudah diselamatkan mengejar kekudusan sebagai ucapan syukur.

Sedangkan Luther dibandingkan Calvin dalam penafsiran khotbah di bukit lebih bersifat ekstrim. Secara teori hermeneutik memang Calvin lebih bertangung jawab daripada Luther. Namun bukan berarti semua penafsiran Luther adalah negatif. Penafsiran Luther memberikan pelajaran bagi para penafsir khotbah di bukit pada zaman sekarang, yaitu kesadaran Luther terhadap expected meaning pada khotbah di bukit. Meskipun Luther sadar bahwa secara intended meaning khotbah di bukit bukanlah bermakna demikian, namun Luther berani menekankan ajaran yang tidak menjadi penekanan dari penulis.

Menekankan yang tidak ditekankan bukanlah kesalahan, menekankan yang salah itulah yang merupakan kesalahan. Ketika seorang penafsir berusaha mencari author's intended meaning, bukan berarti hanya ada one meaning. Kalau hanya one meaning maka Luther sudah melakukan kesalahan. Dalam hal ini Richard Pratt memberikan illustrasi yang baik, dimana author's intended meaning itu seperti berlian yang memiliki banyak sisi. Ini berarti author's intended meaning tidak bersifat single melainkan complex. Bukan satu makna tapi berlimpah makna. Namun ini juga bukan berarti penafsiran bisa bersifat liar. Teknik Historical Criticism itulah yang membangun pagar bagi penafsir. Selama penafsiran didalam pagar maka penafsir bisa menikmati 
kelimpahan ini yang Richard Pratt katakan sebagai legitimate applications. ${ }^{51}$

Oleh karena itu penulis tidak melihat kedua hasil penafsirkan sebagai sebuah permusuhan melainkan sebagai kelimpahan. Bukan saling menyingkirkan namun saling melengkapi. Penafsiran Calvin membangun pagar bagi penafsiran khotbah di bukit. Penafsiran Luther memberikan kelimpan bagi penafsiran khotbah dibukit. Penafsiran Calvin cocok bagi mereka yang ingin menekankan pentingnya mengejar kekudusan. Penafsiran Luther cocok untuk mereka yang ingin menjadikan khotbah di bukit sebagai khotbah penginjilan.

51 Richard L. Pratt, He Gave Us Stories: The Bible Student's Guide to Interpreting Old Testament Narratives (Phillipsburg, N.J.: P \& R Publishing, 1993), 115. 